ISSN 1678-3921

Journal homepage: www.embrapa.br/pab

For manuscript submission and journal contents, access: www.scielo.br/pab
Paulo Henrique Ramos Fernandes ${ }^{(1)}(0$, Crébio José Ávila(2)

Ivana Fernandes da Silva ${ }^{(1 \otimes)}(0$ and Daniele Zulin ${ }^{(1)}$ (0)

(1) Universidade Federal da Grande Dourados, Rodovia Dourados/Itahum, Km 12, Caixa Postal 364, CEP 79804-970 Dourados, MS, Brazil. E-mail: paullo_ramos@hotmail.com, ivanaf.silva@hotmail.com, dani_zulin@hotmail.com

(2) Embrapa Agropecuária Oeste, BR 163, Km 253,6, Caixa Postal 449, CEP 79804-970 Dourados, MS, Brazil.

E-mail: crebio.avila@embrapa.br

$\bowtie$ Corresponding author

Received

November 8, 2018

Accepted

January 27, 2020

How to cite

FERNANDES, P.H.R.; ÁVILA, C.J.; SILVA,

I.F. da; ZULIN, D. Damage by the green-belly stink bug to corn. Pesquisa Agropecuária Brasileira, v.55, e01131, 2020. DOI: https://doi. org/10.1590/S1678-3921. pab2020.v55.01131.

\section{Damage by the green-belly stink bug to corn}

\begin{abstract}
The objective of this work was to evaluate the potential damage of the green-belly stink bug, Dichelops melacanthus, to corn in greenhouse and field conditions. Three trials were carried out. In the greenhouse, corn plants in the V1 stage were evaluated after each of them was infested with one insect in four developmental stages (nymphs of the third, fourth, and fifth instars and adults) during 14 days. In the field, corn plants in four developmental stages (V1, V3, V5, and V7) were infested inside cages with five adult stink bugs, also during 14 days. In another trial in the greenhouse, the same treatments of the field trial were conducted during 14 days, but with an infestation intensity of one bug per plant per pot. The control treatment was without infestation. In all trials, damage scores were attributed to the corn plants and the dry matter of the aerial part of the plants was determined. In the field, stem diameter and grain yield were also evaluated. Third-instar nymphs do not cause significant changes in the dry weight of the aerial part of the plant and in the damage scores, compared with the control treatment. Infestations by adult stink bugs cause more damage to corn plants in the V1 and V3 stages, both in field and greenhouse conditions.
\end{abstract}

Index terms: Dichelops melacanthus, Zea mays, corn growth stages.

\section{Danos do percevejo barriga-verde em milho}

Resumo - O objetivo deste trabalho foi avaliar o potencial de dano do percevejo barriga-verde, Dichelops melacanthus, em plantas de milho, em condições de casa de vegetação e campo. Foram realizados três ensaios. Na casa de vegetação, plantas de milho no estádio V1 foram avaliadas após cada uma ser infestada com um inseto em quatro estádios de desenvolvimento (ninfas de terceiro, quarto e quinto instar e adultos), durante 14 dias. No campo, plantas de milho em quatro estádios de desenvolvimento (V1, V3, V5 e V7) foram infestadas em gaiolas com cinco adultos do percevejo, também durante 14 dias. Em outro ensaio na casa de vegetação, os mesmos tratamentos do ensaio em campo foram conduzidos durante 14 dias, mas com intensidade de infestação de um percevejo por planta por vaso. $\mathrm{O}$ tratamento testemunha foi sem infestação. Em todos os ensaios, foram atribuídas notas de danos às plantas de milho e determinada a massa seca da parte aérea das plantas. No campo, também foram avaliados diâmetro do colmo e rendimento de grãos. As ninfas de terceiro instar não alteram significativamente o peso seco da parte aérea das plantas e as notas de danos, em comparação ao tratamento testemunha. Infestações de adultos do percevejo causam mais danos em plantas de milho nos estádios V1 e V3, tanto em condições de campo quanto de casa de vegetação.

Termos para indexação: Dichelops melacanthus, Zea mays, estágios de desenvolvimento do milho. 


\section{Introduction}

The population increase of phytophagous stink bugs has caused frequent damages to the corn (Zea mays L.) crop. It is believed that the intensification of the corn culture in the off-season, complemented by the increased adoption of the no-tillage system, has provided favorable conditions for the population increase of pests in the agricultural production system (Chocorosqui \& Panizzi, 2004; Brustolin et al., 2017).

The green-belly stink bugs (Dichelops spp.), which usually attack in the early stages of crop development (Roza-Gomes et al., 2011), are considered the main pests associated with corn in the Brazilian Cerrado (Chocorosqui\& Panizzi, 2004), among which Dichelops melacanthus (Dallas, 1851) (Hemiptera: Pentatomidae) stands out as the main species (Brustolin et al., 2017). The first occurrence in corn was recorded in 1993 in the municipality of Rio Brilhante, in the state of Mato Grosso do Sul (Ávila \& Panizzi, 1995). The damage by the $D$. melacanthus stink bug to corn plants occurs when the insect feeds near the collar of the seedlings, penetrating into the plant with their buccal stylet and secreting toxic saliva, which causes the rupture of cells inside the plant tissue (Panizzi \& Lucini, 2019). These salivary secretions result in typical injuries as the corn leaves develop, causing necrosis and yellowing, leaf deformation, or even corn plant tillering (Roza-Gomes et al., 2011; Cruz et al., 2016).

The damage caused by the stink bug can be different when related to corn phenology (Panizzi, 2015). Some agronomic characters, such as grain yield, stem diameter, and the dry matter weight of the aerial part of the plant, can be negatively affected by the intensity of the damage inflicted to the corn plants by the insect (Brustolin et al., 2011). The damage to corn caused by adults of this stink bug is well documented in the literature (Ávila \& Duarte, 2012; Duarte et al., 2015; Smaniotto \& Panizzi, 2015; Panizzi \& Lucini, 2019); however, the damage caused by nymphs of different instars or the influence of this pest on the different developmental stages of the corn plants are still little known. Therefore, the knowledge of the varying susceptibility of corn in different developmental stages may help to guide the management of this pest.

The objective of this work was to evaluate the potential damage of the green-belly stink bug, Dichelops melacanthus, to corn in greenhouse and field conditions.

\section{Materials and Methods}

The green-belly stink bug was reared from individuals collected from the soybean [Glycine $\max (\mathrm{L}$.) Merr.] and corn crops of the experimental area of Embrapa Agropecuária Oeste, located in the municipality of Dourados, in the state of Mato Grosso do Sul, Brazil (22 ${ }^{\circ} 14^{\prime} \mathrm{S}, 54^{\circ} 49^{\prime} \mathrm{W}$, at $437 \mathrm{~m}$ altitude), where the climate is classified as Am, according to Köppen-Geiger. The insects were separated by stages of development (nymphs and adults) and kept in $19 \times 22 \times 10-\mathrm{cm}$ rearing cages, made with plastic jars covered with filter paper.

The adult insects were fed a natural diet composed of a mixture of soybean grains, raw peanut (Arachis hypogaea L.) grains, privet (Ligustrum lucidum W.T.Aiton), green bean (Phaseolus vulgaris L.) pods, and portions of cotton (Gossypium spp.) moistened with water. The cages with the adults and nymphs of the insect were kept in an air-conditioned room at $26 \pm 1{ }^{\circ} \mathrm{C}$, with $60 \pm 10 \%$ relative humidity, under a 14-hour photoperiod. To allow an adequate aeration within the breeding cages, the lids were trimmed to the center and the aperture was covered with voile fabric. Whenever necessary, the food was replenished, the filter paper exchanged, and the cotton moistened in water (Canassa et al., 2017). The eggs of the stink bug were removed daily and packed in new breeding cages containing only a portion of moist cotton. After the nymphs hatched, they received the same food source as the adults.

Three trials were carried out. The first, in the greenhouse of Embrapa Agropecuária Oeste, during the 2016 harvest. There, seeds of the BRS 1055 corn cultivar were sown in plastic pots with a capacity of $11 \mathrm{~L}$, containing a mixture of an Oxisol, the Latossolo Vermelho distroférrico (Santos et al., 2013), and organic matter in a $2: 1$ ratio. Subsequently, the pots were fertilized according to the requirements of the corn crop (Fancelli \& Dourado Neto, 2003), and, five days after plant emergence, thinning was done to leave one plant per pot.

When the corn plants were in the $\mathrm{V} 1$ vegetative stage, characterized by the expansion of the first leaf, one insect of a specific developmental stage was released on each plant per pot to evaluate the potential damage of the stink bug. In this experiment, the evaluated treatments were: T1, third-instar nymph; T2, fourth- 
instar nymph; T3, fifth-instar nymph; T4, 48-hour-old adult; and T5, control, without insect infestation.

The pots containing the corn plants and the insects of each treatment were isolated inside $50 \times 20-\mathrm{cm}$ wire cages covered with voile-type fabric. The plants with the insect infestations were kept in the pots for 14 days, in a greenhouse with natural temperature and humidity conditions. A randomized complete block design was used, with five treatments (insect developmental stages + control), totalizing ten replicates (ten pots containing a corn plant each).

The second trial was conducted in the experimental area of Embrapa Agropecuária Oeste, during the 2016 crop season. In a no-tillage area, furrows were opened and about five seeds of the BRS 1055 corn cultivar were placed per linear meter, at a spacing of $0.45 \mathrm{~m}$ between rows. Plants were fertilized with $250 \mathrm{~kg} \mathrm{ha}^{-1}$ of the formulation 10-18-18 N- $\mathrm{P}_{2} \mathrm{O}_{5}-\mathrm{K}_{2} \mathrm{O}$. No chemical analysis of the soil was made in the area where the experiment was installed.

After corn emergence, groups of five plants were covered with $1.0 \times 1.0 \times 1.5-\mathrm{m}$ cages, made with PVC pipe connections and covered with voile fabric. The treatments represented the different corn plant developmental stages: T1, plants in V1, with the expansion of one leaf; T2, plants in V3, with three leaves; T3, plants in V5, with five leaves; T4, plants in V7, with seven leaves; and T5, plants without infestation since stage V1. Each cage containing the five corn plants was infested with five adult stink bugs for a period of 14 days, except those of the control treatment. The other cultural treatments and irrigation were performed as required by the crop (Fancelli \& Dourado Neto, 2003). The experimental design was a randomized complete block with five treatments (plant phenological stages + control) in five replicates (cages with five plants).

The third trial was also performed in the greenhouse, using the same potting methodology. However, as in the field trial, the treatments represented the different developmental stages of the corn plants: T1, plants in $\mathrm{V} 1$; T2, plants in V3; T3, plants in V5; T4, plants in V7; and T5, plants not infected since V1 (control). Each pot containing a corn plant of a different phenological stage was infested with an adult insect for 14 days, except those in the control treatment, without stink bug infestation. Insects and corn plants were isolated in the same type of cages as in the first trial. The experimental design was also a randomized complete block with five treatments (plant phenological stages + control) in seven replicates (pots with a corn plant).

In all trials in the greenhouse and in the field, pots and PVC cages were inspected daily in order to replace dead insects. At the end of the infestation period, the following damage scores were attributed to the corn plants, according to Torres et al. (2013): score 0, plants free of injuries; score 1, leaves with few spots; score 2, slight leaf damage; score 3, moderate leaf damage; and score 4, plant completely destroyed or dead.

In each trial, the dry mass (dry matter) of the aerial part of the corn plants was also determined. For this, the plants were sectioned to the ground and stored in the greenhouse, at $60^{\circ} \mathrm{C}$, to dry for approximately five days and then weighed using an analytical scale. To evaluate the potential damage caused by the different stages of insect development and in the corn phenological stages, the plants were collected 14 days after insect infestation and 14 days after infestation in the fourth treatment, respectively.

In the field, the grain yield per hectare $\left(\mathrm{kg} \mathrm{ha}^{-1}\right)$ was also determined, at 14\% grain moisture, and stem diameter was obtained by measuring corn plants at a height of $20 \mathrm{~cm}$ from the soil.

The values found for the damage scores, dry matter of the aerial part (grams per plant) of the plants, grain yield, and stem diameter ( $\mathrm{mm}$ ) were subjected to the analysis of variance. When there was a significant treatment effect, the averages were compared by Tukey's test, at 5\% probability. For normality assumption, the data referring to the damage scores of the corn plants were transformed into $\sqrt{x}+0.5$, where $\mathrm{x}$ is the damage score.

\section{Results and Discussion}

In the first trial in the greenhouse, the corn plants infested in the V1 vegetative stage with fourth- and fifth-instar nymphs of the stink bug showed similar damage to those infested with adults. The damage score of those plants was around 3.0, characterizing damaged leaves, which was significantly higher than that below 1 of the plants infested with third-instar nymphs or without pest infestation (control) (Figure 1), characterizing a low intensity of damages (Torres et al., 2013). The minor damage caused by third-instar nymphs could be due to the reduced size of the insect's 
buccal stylet, which probably destroyed less plant tissue cells (Panizzi \& Lucini, 2019) than fourthand fifth-instar nymphs and adults. Although the stink bug began sucking plant sap in the third instar of development, it caused more expressive damage starting at the fourth instar (Panizzi \& Lucini, 2019).

The attack of third-instar nymphs of the stink bug on the corn plants also did not cause significant reductions in the dry matter of the aerial part of the plants, which was similar to that of the control (Figure 2). However, corn plants infested with fourth- and fifth-instar nymphs and adults showed a considerable reduction in dry matter, compared with plants infested with third-instar nymphs or that were not infested. The less-developed buccal structure of small nymphs (Chiaradia et al., 2016; Panizzi \& Lucini, 2019) can be considered the main factor explaining the results obtained in the present study.

In the field trial, the stink bug infestations on the corn plants in different stages of vegetative development had a significant effect on plant stem diameter, mainly in plants infested in the V1 and V3 developmental stages (Table 1). Plants infested in V7 had a diameter similar to that observed in the control treatment, without

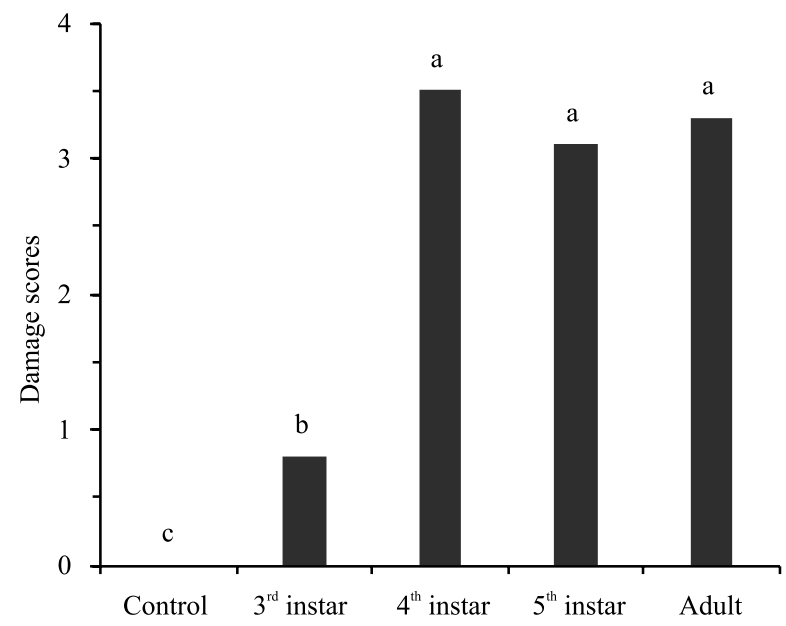

Figure 1. Average values of the damage scores according to the scale of Torres et al. (2013) for BRS 1055 corn (Zea mays) plants in the V1 growth stage, when subjected to infestation with the green-belly stink bug (Dichelops melacanthus) in different stages of development, during 14 days, under greenhouse conditions, in the 2016 crop season, in the municipality of Dourados, in the state of Mato Grosso do Sul, Brazil. Bars followed by equal letters do not differ by Tukey's test, at $5 \%$ probability. pest infestation. Likewise, there was no significant difference in stem diameter between plants infested in stages V5 and V7.

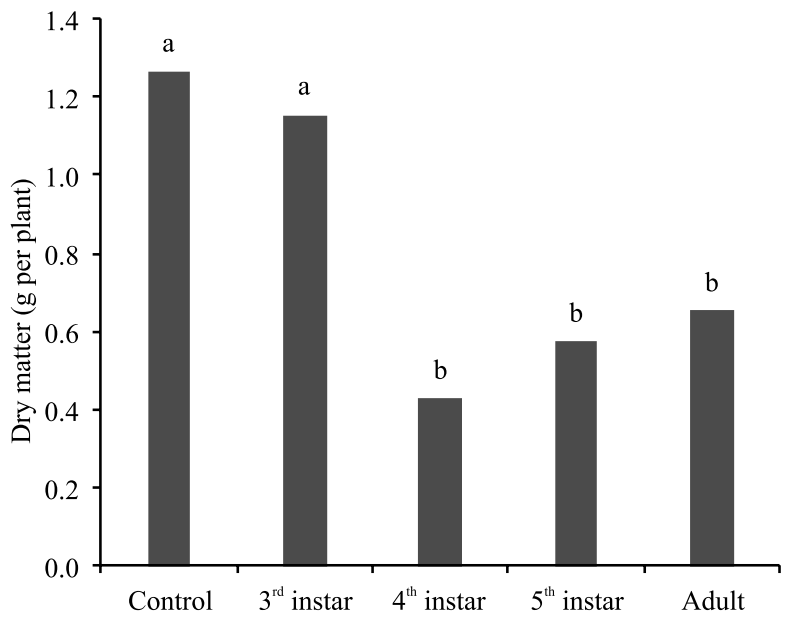

Figure 2. Average values of the dry matter of the aerial part of BRS 1055 corn (Zea mays) plants at the end of the infestation period, after 14 days, with the green-belly stink bug (Dichelops melacanthus) in different stages of development, under greenhouse conditions, in the 2016 crop season, in the municipality of Dourados, in the state of Mato Grosso do Sul, Brazil. Bars followed by equal letters do not differ by Tukey's test, at 5\% probability.

Table 1. Average values ( \pm standard error) of the stem diameter, grain yield, and damage scores obtained for the BRS 1055 corn (Zea mays) plants infested at different growth stages with green-belly stink bug adults (Dichelops melacanthus), during 14 days, under field conditions, in the 2016 crop season, in the municipality of Dourados, in the state of Mato Grosso do Sul, Brazil ${ }^{(1)}$.

\begin{tabular}{lccc}
\hline $\begin{array}{l}\text { Growth stage } \\
\text { of infestation }\end{array}$ & $\begin{array}{c}\text { Stem diameter } \\
(\mathrm{mm})\end{array}$ & $\begin{array}{c}\text { Yield } \\
\left(\mathrm{kg} \mathrm{ha}^{-1}\right)\end{array}$ & $\begin{array}{c}\text { Damage } \\
\text { scores }^{(3)}\end{array}$ \\
\hline Control & $28.2 \pm 0.31 \mathrm{a}$ & $8,100 \pm 745.32 \mathrm{a}$ & $0.00 \mathrm{~b}$ \\
V1 & $21.2 \pm 1.43 \mathrm{~b}$ & $3,980 \pm 823.45 \mathrm{c}$ & $3.12 \pm 0.20 \mathrm{a}$ \\
V3 & $21.1 \pm 1.22 \mathrm{~b}$ & $4,510 \pm 778.86 \mathrm{bc}$ & $2.92 \pm 0.30 \mathrm{a}$ \\
V5 & $24.6 \pm 1.31 \mathrm{ab}$ & $5,612 \pm 681.62 \mathrm{abc}$ & $2.32 \pm 0.12 \mathrm{a}$ \\
V7 & $28.6 \pm 0.45 \mathrm{a}$ & $8,020 \pm 821.61 \mathrm{ab}$ & $0.08 \pm 0.04 \mathrm{~b}$ \\
\hline CV (\%) & 10.61 & 29.96 & 9.22 \\
\hline
\end{tabular}

${ }^{(1)}$ Means followed by equal letters do not differ by Tukey's test, at $5 \%$ probability. ${ }^{(2)}$ Control, without infestation; V1, expansion of one leaf; V3, expansion of three leaves; V5, expansion of five leaves; and V7, expansion of seven leaves. ${ }^{(3)}$ Scale of scores according to Torres et al. (2013). CV, coefficient of variation. 
In the field, the corn plants infested with the stink bug in V1 and V3 also had the lowest grain yields, compared with the control treatment (Table 1). Plants infested in V1 reached only $50 \%$ of the productivity of the control treatment or of plants infested in the V7 stage. Based on the obtained results, the young plants in V1 to V5 were more sensitive to the attack by the stink bug than the more developed plants, such as those in the V7 stage.

The higher susceptibility of new corn plants to the damage by the stink bug may be due to sap feeding or the presence of indole-3-acetic acid, a compound considered toxic to plants in their initial developmental stages (Hori, 2000; Cruz et al., 2016). Since plants define their productive potential in stages V1 to V6 (Fancelli \& Dourado Neto, 2003), which are characterized as susceptible periods to the attack of the stink bug, the farmer must use control measures to avoid economic losses during these first stages of corn development (Cruz et al., 2016).

The highest damage scores were obtained with the infestations carried out in the V1, V3, and V5 developmental stages (Table 1). In V7, the corn damage score was similar to that of the control treatment, evidencing that, at this later stage of development, corn plants are tolerant to the pest attack (Torres et al., 2013). In general, the attacks of the stink bug in the

Table 2. Average values ( \pm standard error) of the dry matter and damage scores obtained for the BRS 1055 corn (Zea mays) plants infested at different stages of development with green-belly stink bug adults (Dichelops melacanthus), during 14 days, under greenhouse conditions, in the 2016 crop season, in the municipality of Dourados, in the state of Mato Grosso do Sul, Brazil ${ }^{(1)}$.

\begin{tabular}{lcc}
\hline $\begin{array}{l}\text { Growth stage } \\
\text { of infestation }\end{array}$ & $\begin{array}{c}\text { Dry matter } \\
\text { (g per plant) }\end{array}$ & $\begin{array}{c}\text { Damage } \\
\text { scores }^{(3)}\end{array}$ \\
\hline Control & $11.6 \pm 0.44 \mathrm{a}$ & $0.00 \mathrm{c}$ \\
V1 & $1.3 \pm 0.24 \mathrm{c}$ & $2.1 \pm 0.34 \mathrm{a}$ \\
V3 & $3.6 \pm 0.42 \mathrm{c}$ & $2.4 \pm 0.34 \mathrm{a}$ \\
V5 & $7.9 \pm 0.65 \mathrm{~b}$ & $1.1 \pm 0.47 \mathrm{~b}$ \\
V7 & $9.3 \pm 0.60 \mathrm{~b}$ & $0.00 \mathrm{c}$ \\
\hline CV (\%) & 21.74 & 52.81 \\
\hline
\end{tabular}

${ }^{(1)}$ Means followed by equal letters do not differ by Tukey's test, at $5 \%$ probability. ${ }^{(2)}$ Control, without infestation; V1, expansion of one leaf; V3, expansion of three leaves; V5, expansion of five leaves; and V7, expansion of seven leaves. ${ }^{(3)}$ Scale of scores according to Torres et al. (2013). CV, coefficient of variation. early stages of corn are the most harmful to the crop, causing greater deleterious effects on crop productivity (Roza-Gomes et al., 2011).

In the other trial in the greenhouse, there was a significant reduction in the average values of the dry matter of the aerial part of the corn plants in all stages of development in which insect infestation occurred, compared with the control treatment (Table 2). As observed in the field trial, the lowest dry matter values were obtained after infestations in V1 and V3, stages in which the corn plant is more susceptible to the pest attack. The reductions in the dry matter of the aerial part of the corn plants are usually more significant in infested plants, as also reported by Duarte et al. (2015).

Despite the high damage potential of the stink bug to corn, the insect does not normally complete its cycle in this crop (Chocorosqui \& Panizzi, 2008; Silva et al., 2013). Studies have shown that soybean allows the full development and reproduction of the stink bug, with a high population increase in the culture (Smaniotto \& Panizzi, 2015; Canassa et al., 2017), providing a large number of insects to attack the off-season corn crop, which is grown in succession to soybean.

In this greenhouse trial, the damage scores of the corn plants were also higher with infestations in vegetative stages V1 and V3, compared with V5 and $\mathrm{V} 7$ and the control treatment (Table 2). The infestations both in the field and greenhouse evidenced the damage caused to corn plants by the green-belly stink bug (Tables 1 and 2).

\section{Conclusions}

1. When corn (Zea mays) plants are infested with third-instar nymphs of the green-belly stink bug (Dichelops melacanthus), there are no alterations in the dry matter of the aerial part of the plant or in the damage scores, compared with the control treatment (without infestation); however, with nymphs of the fourth and fifth instars and adults, there are significant damages and a reduced plant dry matter.

2. When the adult green-belly stink bug infests the corn plants in the V1 and V3 growth stages, it causes a significant deleterious effect on stem diameter and the lowest grain yields and dry matter, both in field and greenhouse conditions. 


\section{Acknowledgments}

To Fundação de Apoio ao Desenvolvimento do Ensino, Ciência e Tecnologia do Estado de Mato Grosso do Sul (Fundect), for granting a Ph.D. scholarship to the first author; and to Coordenação de Aperfeiçoamento de Pessoal de Nível Superior (Capes), for granting a postdoctoral scholarship to the third author.

\section{References}

ÁVILA, C.J.; DUARTE, M.M. Eficiência de inseticidas, aplicados nas sementes e em pulverização, no controle do percevejo barriga-verde Dichelops melacanthus (Dallas) (Hemiptera: Pentatomidae), na cultura do milho. BioAssay, v.7, art.6, 2012. DOI: https://doi.org/10.14295/BA.v7.0.72.

ÁVILA, C.J.; PANIZZI, A.R. Occurrence and damage by Dichelops (Neodichelops) melacanthus (Dallas) (Heteroptera: Pentatomidae) on corn. Anais da Sociedade Entomológica do Brasil, v.24, p.193-194, 1995.

BRUSTOLIN, C.; BIANCO, R.; NEVES, P.M.O.J. Inseticidas em pré e pós-emergência do milho (Zea mays L.), associados ao tratamento de sementes, sobre Dichelops melacanthus (Dallas) (Hemiptera: Pentatomidae). Revista Brasileira de Milho Sorgo, v.10, p.215-223, 2011. DOI: https://doi.org/10.18512/1980-6477/ rbms.v10n3p215-223.

BRUSTOLIN, C.; NEVES, P.M.O.J.; BIANCO, R.; BORTOLOTTO, O.C. Tratamento de sementes de milho para controlar Dichelops melacanthus em diferentes tipos de solo. Revista Brasileira de Milho Sorgo, v.16, p.13-21, 2017. DOI: https://doi.org/10.18512/1980-6477/rbms.v16n1p13-21.

CANASSA, V.F.; BALDIN, E.L.L.; BENTIVENHA, J.P.F.; PANNUTI, L.E. da R.; LOURENÇÃO, A.L. Resistance to Dichelops melacanthus (Hemiptera: Pentatomidae) in soybean genotypes of different maturity groups. Bragantia, v.76, p.257265, 2017. DOI: https://doi.org/10.1590/1678-4499.068.

CHIARADIA, L.A.; NESI, C.N.; RIBEIRO, L.P. Nível de dano econômico do percevejo barriga-verde, Dichelops furcatus (Fabr.) (Hemiptera: Pentatomidae), em milho. Agropecuária Catarinense, v.29, p.63-67, 2016.

CHOCOROSQUI, V.R.; PANIZZI, A.R. Impact of cultivation systems on Dichelops melacanthus (Dallas) (Heteroptera: Pentatomidae) population and damage and its chemical control on wheat. Neotropical Entomology, v.33, p.487-492, 2004. DOI: https://doi.org/10.1590/S1519-566X2004000400014.

CHOCOROSQUI, V.R.; PANIZZI, A.R. Nymph and adult biology of Dichelops melacanthus (Dallas) (Heteroptera: Pentatomidae) feeding on cultivated and non-cultivated host plants. Neotropical Entomology, v.37, p.353-360, 2008. DOI: https://doi.org/10.1590/ S1519-566X2008000400001.
CRUZ, I.; BIANCO, R.; REDOAN, A.C.M. Potential risk of losses in maize caused by Dichelops melacanthus (Dallas) (Hemiptera: Pentatomidae) in Brazil. Revista Brasileira de Milho Sorgo, v.15, p.386-397, 2016. DOI: https://doi.org/10.18512/1980-6477/ rbms.v15n3p386-397.

DUARTE, M.M.; ÁVILA, C.J.; SANTOS, V. Danos e nível de dano econômico do percevejo barriga-verde na cultura do milho. Revista Brasileira de Milho Sorgo, v.14, p.291-299, 2015. DOI: https://doi.org/10.18512/1980-6477/rbms.v14n3p291-299.

FANCELLI, A.L.; DOURADO NETO, D. Milho: ecofisiologia e rendimento. In: FANCELLI, A.L.; DOURADO NETO, D. (Org.). Tecnologia da produção de milho. Piracicaba: ESALQ/USP, 2003. p.157-170.

HORI, K. Possible causes of disease symptoms resulting from the feeding of phytophagous Heteroptera. In: SCHAEFER, C.W.; PANIZZI, A.R. (Ed.). Heteroptera of economic importance. CRC Press: Boca Raton, 2000. p.11-35.

PANIZZI, A.R. Growing problems with stink bugs (Hemiptera: Heteroptera: Pentatomidae): species invasive to the U.S. and potential Neotropical invaders. American Entomologist, v.61, p.223-233, 2015. DOI: https://doi.org/10.1093/ae/tmv068.

PANIZZI, A.R.; LUCINI, T. Body position of the stink bug Dichelops melacanthus (Dallas) during feeding from stems of maize seedlings. Brazilian Journal of Biology, v.79, p.304-310, 2019. DOI: https://doi.org/10.1590/1519-6984.18250.

ROZA-GOMES, M.F.; SALVADORI, J.R.; PEREIRA, P.R.V. da S.; PANIZZI, A.R. Injúrias de quatro espécies de percevejos pentatomídeos em plântulas de milho. Ciência Rural, v.41, p.1115-1119, 2011. DOI: https://doi.org/10.1590/S010384782011005000081 .

SANTOS, H.G. dos; JACOMINE, P.K.T.; ANJOS, L.H.C. dos; OLIVEIRA, V.A. de; LUMBRERAS, J.F.; COELHO, M.R.; ALMEIDA, J.A. de; CUNHA, T.J.F.; OLIVEIRA, J.B. de. Sistema brasileiro de classificação de solos. 3.ed. rev. e ampl. Brasília: Embrapa, 2013. 353p.

SILVA, J.J.; VENTURA, M.U.; SILVA, F.A.C.; PANIZZI, A.R. Population dynamics of Dichelops melacanthus (Dallas) (Heteroptera: Pentatomidae) on host plants. Neotropical Entomology, v.42, p.141-145, 2013. DOI: https://doi.org/10.1007/ s13744-012-0104-2.

SMANIOTTO, L.F.; PANIZZI, A.R. Interactions of selected species of stink bugs (Hemiptera: Heteroptera: Pentatomidae) from leguminous crops with plants in the Neotropics. Florida Entomologist, v.98, p.7-17, 2015. DOI: https://doi.org/10.1653/024.098.0103.

TORRES, A.B.A.; OLIVEIRA, N.C. de; OLIVEIRA NETO, A.M. de; GUERREIRO, J.C. Injúrias causadas pelo ataque dos percevejos marrom e barriga verde durante o desenvolvimento inicial do milho. Journal of Agricultural Science, v.2, p.169-177, 2013. 